CHAPTER 14

\title{
Prisons, the law and overcrowding
}

\author{
Clare Ballard
}

'Going to prison is like dying with your eyes open.'

Bernard Kerik, former New York City police commissioner

\section{INTRODUCTION}

This chapter is about a long-standing problem in the South African criminal justice sector that, despite an overhaul of the prison legislation after the enactment of the final Constitution, continues, twenty years on, to plague the Department of Correctional Services and, of course, those who are incarcerated in the country's prisons. I examine both the causes and the effects of overcrowding as well as the constitutional implications, and argue that currently the rights of inmates detained in overcrowded prisons are being infringed and that curative measures on the part of the state are needed urgently. I discuss what remedial measures are, or could be, available, some of which could be employed immediately, and others over the medium to long term.

\section{A FEW PRELIMINARY POINTS}

I use the term 'inmates' to refer to both sentenced offenders and those awaiting trial. The latter, to whom I shall refer as 'remand detainees', are detainees who have already been formally charged before a court, are awaiting trial, or who have not yet been sentenced 
and who are being detained in a prison. Approximately one-third of the prison population is composed of these remand detainees and they are thus a significant element in the problem of overcrowding (Judicial Inspectorate 2010/11). The term 'overcrowding' is used in this chapter as a description only of the ratio of inmates to rated capacity. Haney (2006) makes the important point that the term could include the extent to which a prison accommodates more inmates than its infrastructure can 'humanely accommodate, meaning a prison without adequate medical facilities for its population could be "overcrowded" even though, technically, it is not accommodating more inmates than that for which it was designed'. Although it is likely that South African prisons are overcrowded in the broader sense, the statistical information available is not sophisticated enough to support an argument along such lines. So, in this chapter, we consider only the numbers of inmates.

\section{PRISON LAW AND THE CONSTITUTION}

Since the advent of South African democracy the law in respect of prisons and punishment has been reformed in significant ways. Reform was prompted, of course, by the interim and then final Constitutions, the latter adopted in 1996. The value-laden text of the Bill of Rights makes it quite clear that all detainees, awaiting trial or sentenced, are entitled to a certain standard of treatment - 'conditions of detention consistent with human dignity' - and a set of specific rights (the Constitution). The relevant legislation giving effect to these rights, the Correctional Services Act 111 of 1998, came into force during 2004. The Act and its regulations include precise requirements for all aspects of the treatment of prisoners: accommodation, nutrition, clothing, medical treatment, discipline and methods of restraint. At the core of the Act is an acknowledgment that the prison system should ensure the safety and the protection and fulfilment of the rights of inmates, and promote the 'social responsibility and human development' of all sentenced inmates. Given the history of corrections in South Africa, the Act represents a fundamental shift in focus from its predecessor, the Correctional Services Act of 1959, which spoke little of the rights of inmates and dealt primarily with the administration of the prison system (Van Zyl Smit 2001). Five months after the final promulgation of the Act, the Department of Correctional Services released the White Paper on Corrections in South Africa which made it clear that one of the central purposes of the Department was the rehabilitation of prisoners (Muntingh 2005). In addition, as Muntingh states, it is in part a 'confession on the part of the Department for previous practices and policies'. Indeed, in his foreword to the White Paper the then minister of correctional services said:

The White Paper on Corrections in South Africa presents the final fundamental break with a past archaic penal system and ushers in a start to our second decade of freedom where prisons become correctional centres of rehabilitation and offenders are given 
new hope and encouragement to adopt a lifestyle that will result in a second chance towards becoming the ideal South African citizen.

Prior to the enactment of the final Constitution and the legislation and policy described above, the common law had made great strides towards the protection of the rights of inmates. In 1993, the Appellate Division, in the matter of Minister of Justice v Hofmeyr 1993 (3) SA 131 (A), held that all the fundamental rights of prisoners survived incarceration - a notion known as the residuum principle. ${ }^{1}$ This was an important moment in the history of prisoners' rights, for the Appellate Division had effectively reinstated a principle set down in a 1911 decision $^{2}$ which had been systematically eroded over the years through draconian apartheid-era detention legislation and judicial decisions favourable to the executive. The Hofmeyr judgment has continued to form the basis of South African jurisprudence on prisoners' rights which, since the advent of the final Constitution, have 'been given fresh impetus by a number of our constitutional values such as dignity, equality and humanity' (Van Zyl Smit 2005). Perhaps one of the most important decisions on prisoners' rights was the first judgment of the Constitutional Court, S v Makwanyane 1995 (3) SA 391 (CC), renowned for having declared the death penalty unconstitutional. In doing so, the court adopted the Kantian notion that '[the right to] human dignity precludes treating individuals as mere objects or means to an end' (Botha 2009). The Makwanyane court stated:

The death penalty ... instrumentalises the offender for the objectives of state policy.

That is dehumanising. It is degrading and it violates the rights to respect for and protection of human dignity embodied in Section 10 of the Constitution.

Several years later, this idea was repeated by the Constitutional Court in S v Dodo 2001 (3) SA 382 (CC), which considered the constitutionality of minimum sentencing legislation (Criminal Law Amendment Act 1997). The Court stated that the imposition of a disproportionately severe sentence without sufficient inquiry into whether such a sentence was a measure justified by the severity of the offence would be:

... to ignore, if not to deny, that which lies at the very heart of human dignity. Human beings are not commodities to which a price can be attached; they are creatures with inherent and infinite worth; they ought to be treated as ends in themselves, never merely as means to an end.

The Constitutional Court's emphasis on the value of self-actualisation cemented, so to speak, the idea that the penal system should be a restorative and rehabilitative institution, no longer defined by the retributive and punitive policies of its past. 


\section{CAUSES OF PRISON OVERCROWDING}

\section{Crime, policing and policy - looking back}

Although the legislature and judiciary appeared to bear down in favour of prisoners' rights when they did, the opposite was true of policing and crime control. During the 1990s the levels of crime went up quite dramatically in South Africa, ${ }^{3}$ and the criminal justice system did little to assuage the perception that the government was failing to respond to the problem effectively. In 2000, only 610000 of the 2.6 million crimes recorded by the police were referred to the National Prosecuting Authority (NPA); although the NPA achieved convictions in the majority of cases they prosecuted, this represented only 8 per cent of the 2.6 million reported crimes (Schonteich 2003). Accordingly, the notion that the criminal justice system was no longer a capable guardian of public safety and security became more pervasive, as did 'community policing' (vigilante or otherwise) among poorer communities, and a wholesale movement towards a reliance on the private security sector among the middle classes (Van der Spuy 2000). In addition, according to the Independent Complaints Directorate, there was a 'growing, popular perception that constitutional rights for criminals [were] being protected above those of their victims' (Schonteich 2003).

The government responded with a surge in militarised police force. There was a marked increase in police clampdowns, as well as saturation policing, which required that certain areas be sealed off and people and property searched (Van der Spuy 2000). In one operation named Sword and Shield, more than 300000 suspects were arrested during 1996 and 1997 (Matthews 2000). Unfortunately, as Subramanian (2013) notes, there were no efforts to equip the courts and remand detention facilities in the face of the inevitable rise in the number of people arrested and detained. The consequence, of course, was the flooding of an already over-burdened court system and of poorly equipped prisons.

The legislature responded with a spate of statutory amendments to the bail provisions of the Criminal Procedure Act. These resulted in the controversial reverse onus provisions which stipulate that a suspect must be denied bail when charged with certain serious offences unless able to prove that 'exceptional circumstances' exist, satisfying the presiding officer that it is in the interests of justice to release him or her. Unsurprisingly, the prison population escalated substantially: in 1995 it was just under 120 000; in 2002, it was approximately 190 000. From 2005 onwards the prison population tapered off somewhat, and in March 2013 it was 158165.

A rehabilitative prison environment, responsive to the needs of individuals, cannot exist when prisons are overburdened, which is why the contrast in response on the part of the state and judiciary towards arrested suspects, and the treatment of prisoners, is rather bizarre. But it illustrates, perhaps, that legislation or legislative intent cannot change the status quo if political sentiment is lacking.

\section{Remand detention}

The crime rate in South Africa began to drop steadily from 1999-2000, which may explain the softening of policing tactics around this time and the consequent reduction 
of the prison population (Crime Stats SA). In 2012-2013, however, the crime rate was the lowest it has been in the last ten years, yet the prison population is still far greater than it was in 1995. Importantly, sentenced admissions do not appear to be a driving force in the general prison population - on the contrary, the sentencing rate dropped significantly between 2001 and 2007-2008 (from more than 200000 total sentenced admissions per year to approximately 80000 in 2010-2011), and, after increasing slightly during the years 2008-2010, reached an all-time low in 2010-2011 (Redpath 2013). This happened despite the introduction of a more punitive sentencing framework ${ }^{4}$ and the fact that the rate of prosecutorial referrals from the police to the NPA did not decline during this period (Redpath 2012). The number of yearly admissions into remand detention fluctuated between 250000 and 300000 during the same period (dropping just below 250000 in 2010-2011). The number of remand detention admissions per sentenced admissions, however, grew considerably between 2000-2001 and 2007-2008, from just below 1.5 to more than three (Redpath: 2013). This explains the more or less constant number of the total inmate population from 2005-2006 to 2012-2013 and also suggests that the remand detention numbers are indeed a significant driving factor in the prison population even though they constitute only 30 per cent of it, far below most other African and Middle East countries (World Prison Brief).

\section{PRISON OVERCROWDING - SOME CONTEXT}

Despite the legal and policy developments within the penal framework that have taken place since the advent of democracy, conditions in South African prisons have remained poor, and they are overcrowded.

Several African countries are classed as having some of the world's most overcrowded prisons (World Prison Brief). Benin, for example, has the second highest occupancy rate in the world - 307.1 per cent. The country reports of Special Rapporteur for Prisons and Conditions of Detention have revealed some alarming statistics on African prisons over the years. In Côte d'Ivoire, in 2006, a prison designed to accommodate 1500 prisoners was actually accommodating 4 034. In 2004, the Special Rapporteur, on a mission to Ethiopia, noted that 'apart from [one prison] all detention facilities visited were overcrowded, some holding inmates more than thrice their capacity' (Dankwa 2008).

South Africa, at 133 per cent occupancy, is well below the startling figures representing the world's ten most overcrowded prisons, four of which belong to African countries according to the World Prison Brief. Averages can be misleading, however. The occupancy rates of individual prisons paint a far clearer picture of the conditions of detention to which inmates are subjected. The Judicial Inspectorate for Correctional Services acknowledges this in its 2011-2012 report when it states: 'Although overcrowding on a national level is reflected in an occupancy level of 133 per cent, there is a vast difference between overcrowding in individual centres, with some centres extremely overcrowded and some operating below capacity.' 
It is therefore unsurprising that the provinces with the highest occupancy rates have the country's most overcrowded prisons, which range between 200 and 250 per cent capacity (Judicial Inspectorate 2010/11). It is important to mention at this stage that the Department of Correctional Services's own standing orders stipulate that the minimum permissible cell area per prisoner, excluding areas taken up by ablution facilities, walls and pillars and personal lockers (not built-in) in the cell, must be $3.344 \mathrm{~m}^{2}$ in respect of ordinary communal cells. Capacity is determined according to the Department's own space norm of $3.334 \mathrm{~m}^{2}$ per prisoner in a communal cell and $5.5 \mathrm{~m}^{2}$ in ordinary single cells. This regulation is just below the Committee for the Prevention of Torture's recommended minimum of $4 \mathrm{~m}^{2}$ per prisoner in a communal cell. ${ }^{5}$

Despite the existence of legislative measures intended to alleviate the burden on correctional facilities and the Judicial Inspectorate having consistently raised the problem of prison overcrowding since its first published Annual Report in 2000, the Department of Correctional Services itself admits that 'overcrowding remains high' (Department Annual Report: 2009/2010).

\section{THE EFFECTS OF PRISON OVERCROWDING}

The effects of prison overcrowding, which go far beyond simple discomfort, are crucial to the case in favour of the reduction of the prison population. Simply put, overcrowding hinders the realisation of inmates' other rights of nutrition, medical treatment and exercise. The case of Lee $v$ Minister of Correctional Services 2011 (2) SACR 603 (WCC) illustrates this well. The plaintiff was detained for four and a half years while awaiting trial, during which time he contracted tuberculosis. The judgment relates the evidence of expert witnesses describing the conditions of detention:

The average overcrowding in 2003 was around 234 per cent to 236 per cent. Overcrowding meant that disease could be spread more easily, and, as far as TB was concerned, the more people were packed into a cell, the greater the prospects that bacteria which were coughed up would infect other inmates. [The medical expert] regularly saw overcrowded cells in the maximum security prison and testified that his first impression was one of dinginess and squalor, because blankets are often used to protect or cover up places within a cell. He described the situation as dehumanising.

The effects of overcrowding also include less obvious consequences, and empirical research, although somewhat dated, has shown that 'crowding significantly worsens the quality of institutional life and increases the destructive potential of imprisonment' (Haney 2006). A brief summary of some of this empirical research, which originates, for the most part, in the United States, is as follows: 
i. The nature of the stress and degree of uncertainty with which inmates in situations of overcrowding must cope can result in physical and psychological harm. Haney (2006) states:

Crowded conditions heighten the level of cognitive strain that prisoners experience by introducing social complexity, turnover, and interpersonal instability into an already dangerous prison world in which interpersonal mistakes or errors in social judgments can be fatal. [O]f course, overcrowding also raises collective frustration levels inside prisons by generally decreasing the resources available to prisoners confined in them. The amount of things prisoners can accomplish on a day-to-day basis is compromised by the sheer number of people in between them and their goals and destinations.

ii. Studies have shown an association between poorly regulated and overcrowded prisons and the occurrence of disciplinary infractions as well as higher rates of assault, rape and sexual violence (Haney 2006). Linked to this is the organisational strain that overcrowded prisons experience. Congested prisons lead to the 'less careful classification, monitoring and managing of inmates with psychological problems or who pose a threat of violence' (Haney 2006). The correlation between overcrowding and reduced management efficiency and increased recidivism is unsurprising.

Although there is very little South African empirical research on prison overcrowding, it is notable that the most recent reported incidents of prison violence occurred in some of the country's most overcrowded prisons. ${ }^{6}$ One cannot escape the conclusion that, for sentenced inmates, prison overcrowding, in addition to its adverse effects on the rights enumerated in section 35(2)(e) of the Constitution, frustrates an important purpose of a sentence of imprisonment: namely, as the Act states, to promote the 'social responsibility and human development of all sentenced offenders' and ensure that the offender leads a 'crime free life in the future'.

There has not yet been a direct court challenge to prison overcrowding, although the issue has arisen indirectly. In fact, there are a limited number of cases directly involving section 35(2)(e) of the Constitution. ${ }^{7}$ Prisoners' rights litigation has generally involved the alleged infringement of certain discrete rights such as the right to education, privacy, health and the right to vote.

\section{THE CONSTITUTION AND THE LAW REDUX}

Section 35(2)(e) of the Constitution, which applies to both sentenced and awaiting trial prisoners, states that: 'Everyone who is detained, including every sentenced prisoner, has the right to conditions of detention that are consistent with human dignity, including at least exercise, and the provision, at state expense, of adequate accommodation, nutrition, reading material and medical treatment.' 
Chapter Three of the Correctional Services Act, entitled 'custody of all inmates under conditions of human dignity', gives effect - so to speak - to section 35(2)(e) of the Constitution. Put differently, it sets out in greater detail the requirements of the Constitution. Accordingly, prison conditions which fall below the requirements of Chapter Three are a violation of the standards expressed in section 35(2)(e) and may well amount to 'inhuman or degrading' treatment or punishment, a violation of section 12(1)(e) of the Constitution. The Act and its regulations require the following in respect of accommodation:

i. Cell accommodation must have sufficient floor and cubic space to enable the prisoner to move freely and sleep comfortably within the confines of the cell;

ii. All accommodation must be ventilated according to regulation;

iii. Cells must be sufficiently lit by natural and artificial light so as to enable the prisoner to read and write;

iv. There must be sufficient ablution facilities available to prisoners at all times which include hot and cold water, and such facilities must be partitioned-off from sleeping areas; and

v. Each prisoner must have his or her own separate bed.

Based on the current occupation rate, this means that prisoners at the most crowded facilities have between $1.3 \mathrm{~m}^{2}$ and $1.7 \mathrm{~m}^{2}$ of floor space. Although adjudicatory bodies around the world have expressed a range of acceptable floor space standards, as Steinberg (2005) notes: 'When floor space drops to as little as $2.1 \mathrm{~m}^{2}$ per prisoner the grey areas in international jurisprudence narrow considerably.' Admittedly, measurements like these will never be an entirely accurate reflection of prison conditions, even at the most crowded facilities. The nature of prison accommodation varies considerably, not only between prisons, but also within each prison itself. For example, for security or disciplinary reasons, a number of prisoners may be grouped together in a communal cell, rendering it severely overcrowded, whereas the remainder of the prison population remains well below maximum capacity. A situation like this would not reflect, statistically, as problematic. Nevertheless, it is safe to assume, at the very least, that correctional facilities accommodating inmates at more than 200 per cent capacity are overcrowded to the point where it is almost certainly a violation of section $35(2)(\mathrm{e})$ of the Constitution and, in more extreme circumstances, section $12(1)(d)$, the 'right not to be treated or punished in a cruel, inhuman or degrading way'.

International tribunals have made such findings. The European Court of Human Rights (ECHR), for example, has found that cell size and overcrowding were indeed issues relevant to its determination that such conditions amounted to a violation of article 3 of the European Convention on Human Rights, which prohibits torture and inhuman or degrading treatment or punishment. ${ }^{8}$ In Kalashnikov v Russia (No. 47095/99), the ECHR considered the effect of overcrowding on the applicant at a certain Russian prison in which he had been detained. At any given time, the ECHR observed: 'There was 0.9-1.9 square 
metres of space per inmate in the applicant's cell.' It found that the severely overcrowded and unsanitary environment and its detrimental effect on the applicant's health and wellbeing amounted to degrading treatment, a violation of article 3 of the Convention. It noted, too, that poor sleeping conditions as well as the 'general commotion and noise from the large number of inmates' - all of which were caused by acute overcrowding constituted a heavy physical and psychological burden on the applicant.

\section{REMEDIAL MEASURES}

There are currently 55038 prisoners accommodated in thirty-four prisons that are 175 per cent or more full. These prisons have an average capacity of 773 beds (the median being 557 beds). Of the prisoners, 49.9 per cent are sentenced and 50.1 per cent are unsentenced. If the capacity of all prisons with an occupancy rate of 175 per cent and more were to be added and spread over the entire group, the occupation rate would be 206 per cent. If releases were to be targeted at prisons that were 175 per cent or more full, it would require the release of 27976 prisoners to bring them to 100 per cent occupancy. If the aim were to bring the occupancy rate down to 175 per cent, it would require the release of 8253 prisoners. Occupancy of 150 per cent would require the release of 14828 prisoners, and 125 per cent would require the release of 21402 prisoners.

As I have explained above, the remand detention population is an important driving factor and, indeed, many of the country's prisons are overcrowded as a result of it (Judicial Inspectorate 2012). In some correctional facilities where overcrowding has reached a 'critical level' remand detainees account for 52 per cent of the inmate population (Judicial Inspectorate 2009/2010). On 31 March 2012, the awaiting trial detainee population in South Africa was 46351 , approximately 30 per cent of the total inmate population and almost double the Department of Correctional Services's proposed benchmark figure of 25 000. As with many human rights concerns, the poor, who cannot afford bail or the services of a lawyer, will suffer the worst of the effects of remand detention: exposure to torture, extortion, disease and the arbitrary actions of police and corrupt officials (Berry 2011).

There are legislative and policy provisions that could be used to alleviate overcrowding in remand detention facilities. First, the Criminal Procedure Act provides for the release of an accused on bail if a magistrate is satisfied that 'the prison population of a particular prison is reaching such proportions that it constitutes a material and imminent threat to ... human dignity, physical health or safety.... The provision only applies, however, to remand detainees who have been granted bail but cannot afford it and are incarcerated pending trial - they account for about 24 per cent of the remand detainee population (Damons 2008) and so this provision could certainly prove to be effective.

Second, the Criminal Procedure Act states that a magistrate or judge before whom criminal proceedings are pending '... shall investigate any delay in the completion of proceedings which appears to the court to be unreasonable and which could cause 
substantial prejudice to the ... accused'. That an accused has been incarcerated in overcrowded conditions for an unnecessarily long period would certainly have an effect on the 'personal circumstances of the accused', one of the factors the court must take into account in carrying out such an inquiry.

Third, as required by the NPA's awaiting trial detainees (ATD) guidelines, prosecutors should reconsider bail if an accused has been in custody for longer than six months and ensure that the investigations and presentation of the state's evidence are fast-tracked. ${ }^{9}$ These processes could be made more efficient if the prosecutorial agents referred to the information tabled before Parliament in terms of section 342A(7) of the Criminal Procedure Act. This stipulates that the National Director of Public Prosecutions must submit, within fourteen days after the end of January and of July of each year, a report to the cabinet member responsible for the administration of justice, in respect of each accused whose trial has not yet started with the leading of evidence and who, by the end of the month in question, has been in custody for a continuous period exceeding eighteen months from the date of arrest (where the trial is to be conducted in a High Court); or twelve months from date of arrest (if it is to be conducted in a regional court); or six months from date of arrest (if it is to be conducted in a magistrate's court). Ultimately, however, the successful reduction of the remand detention population depends on the implementation of effective backlog-reduction programmes and the Department of Justice and Constitutional Development should prioritise such initiatives. ${ }^{10}$

For sentenced prisoners, there is, admittedly, not much by way of legislative assistance. Nevertheless, given the extent to which sentenced facilities are overcrowded, the state of affairs is undoubtedly unconstitutional. The solution is not necessarily the building of more prisons, nor is it the transferring of prisoners from overcrowded prisons to other prisons in areas far from their own communities and visitors. Rather, the Department should add the necessary capacity to those prisons that simply require more bed space - far easier and cheaper than building new prisons from scratch (as was shown in the most recent Inspectorate's report); and with the level of overcrowding and constitutional urgency as they are it is remarkable that this has not yet been done to a sufficient standard. Failing the Department's action, however, there is reason to believe that litigation may be successful although success is likely to turn on the potential effectiveness of the available remedies. Given the courts' understandable reluctance to quantify constitutional minimum standards, ${ }^{11}$ the most probable and the best remedy would be a declaration, in broad terms, that the current state of prison overcrowding is a violation of constitutional standards and amounts to a violation of the right to be detained in conditions consistent with human dignity. A court, ideally, could grant a supervisory order directing the relevant government departments to remedy the problem within a certain time-frame, failing which a certain number of suitable prisoners would be released to bring the accommodation capacity within an acceptable range. ${ }^{12}$ An 'acceptable range' could even be the Department's own benchmark of $3.344 \mathrm{~m}^{2}$ per prisoner - at least as a start. A targeted release programme may provide some immediate relief to the problem of overcrowding, but it would make little sense to release prisoners only to let the prison 
population numbers rise all over again, and it is essential to propose policy measures that will be applied consistently so that the prisoner population remains stable (Giffard 2006). To the extent that overcrowding is driven by the sentenced population, it is perhaps apposite to revisit the mandatory minimum sentences legislation, especially in light of the fact that it was intended to operate as a temporary two-year measure.

Given the 'progressive content of the law', the state of South African prisons is inexcusable (Jansen 2011). And for too long now penal reform does not seem to have been made a priority either by government or by society at large. The solutions to the problem of overcrowding are not simple. Its causes are systemic and vary across the backlogs, poor management and maladministration of a range of government departments. An informed and meaningful effort by stakeholders would go a long way towards alleviating the numerous and severe effects suffered by thousands of inmates. But surely, twenty years after the enactment of the Constitution, the rights of inmates can no longer be ignored.

\section{REFERENCES}

Ballard C and R Subramanian (2013) Remand detention and pretrial services: A few lessons from the past. South African Crime Quarterly 44.

Berry D (2011) The socioeconomic impact of pre-trial detention: A global campaign for pre-trial justice. Report, Open Society Foundation and United Nations Development Programme.

Dankwa V (2008) Overcrowding in African prisons. In Sarkin J (ed.) Human Rights in African Prisons. Athens, OH: Ohio University Press.

Haney C (2006) The wages of prison overcrowding: Harmful psychological consequences and dysfunctional correctional reactions. Washington University Journal of Law and Policy 22: 265-294.

Jansen R and T Achiume (2011) Prison conditions in South Africa and the role of public interest litigation since 1994. South African Journal of Human Rights 218: 183-191.

Karth V, M O'Donovan and J Redpath (2008) Between a rock and a hard place: Bail decisions in three South African courts. Open Society Foundation for South Africa report.

Matthews I (2000) Government responses in South Africa: Policy and implementation (2000). Crime and Policing in Transitional Societies, 30 August-1 September 2000, Jan Smuts House, University of the Witwatersrand, Johannesburg.

Muntingh L (2005) Offender rehabilitation and reintegration: Taking the White Paper on corrections forward. Civil Society Prison Reform Initiative Research Paper No. 10.

Muntingh L and C Giffard (2006) The effect of sentencing on the size of the South African prison population, Open Society Foundation for South Africa report.

Paschke R (1999) Process and impact assessment of the pre-trial services demonstration project. Bureau of Justice Assistance Report No. 3.

Redpath J (2013) Presentation on Remand Detention in South Africa, delivered at CSPRI round-table event on 23 May 2013.

Redpath J (2012) Failing to prosecute? Assessing the state of the National Prosecuting Authority in South Africa. Institute for Security Studies Monograph 186.

Rodley N and M Pollard (2011) The Treatment of Prisoners under International Law. Third ed. Oxford: Oxford University Press.

Sarkin J, E Steyn, D Van Zyl Smit and R Paschke R (2000) The Constitutional Court's bail decision: Individual liberty in crisis? South African Journal of Human Rights 16: 292-312.

Schonteich M (2003) Criminal justice policy and human rights in the new South Africa. Queensland University of Technology Law and Justice Journal 3(2): 333-348. 
Sekhonyane M and A Louw (2002) Violent justice, vigilantism and the state's response. Institute for Security Studies, Monograph 72.

Steinberg J (2005) Prison overcrowding and the constitutional right to adequate accommodation in South Africa. Centre for the Study of Violence and Reconciliation publication, available at http:// www.csvr.org.za/wits/papers/papjonn2.htm3.

Van der Spuy E (2000) Crime and its discontent: Recent South African responses and policies. Crime and Policing in Transitional Societies, 30 August-1 September 2000, Jan Smuts House, University of the Witwatersrand, Johannesburg.

Van Zyl Smit D (2005) Sentencing. In Woolman S and M Bishop M (eds) Constitutional Law of South Africa OS 2005.

World Prison Brief, International Centre for Prison Studies. Available at http://www.prisonstudies.org/ info/worldbrief/wpb_stats.php?area=all\&category=wb_occupancy.

Zysk K, F Dunkel and D van Zyl Smit (2001) Imprisonment Today and Tomorrow: International Perspectives on Prisoners' Rights and Prison Conditions. Second ed. Leiden: Brill Academic Publishers.

\section{Case law}

Minister of Justice $v$ Hofmeyr 1993 (3) SA 131 (A)

Sv Makwanyane 1995 (3) SA 391 (CC)

$S v$ Dodo 2001 (3) SA 382 (CC)

Lee $v$ Minister of Correctional Services 2011 (2) SACR 603 (WCC)

Kalashnikov v Russia (No. 47095/99) 2002-VI

Masangano v Attorney General \& Others [2009] MWHC 31 (9 November 2009)

Whittaker $v$ Roos and Bateman; Morant $v$ Roos and Bateman 1912 AD 92

Rossouw $v$ Sachs 1964 (2) SA 551(A)

Strydom v Minister of Correctional Services 1999 (3) BCLR 342 (W)

Kudta $v$ Poland No 30210/96) ECHR 2000-XI

Mazibuko and Others v City of Johannesburg and Others 2010 (3) BCLR 239 (CC); 2010 (4) SA 1 (CC)

Brown v Plata 563 U.S. (2011)

\section{NOTES}

1 The residuum principle is now captured in section 4(b) of the Correctional Services Act, which states that: 'the duties and restrictions imposed on inmates to ensure safe custody by maintaining security and good order must be applied in a manner that conforms with their purpose and which does not affect the inmate to a greater degree or for a longer period than necessary.' The Act also requires that the 'minimum rights of inmates entrenched in the Act must not be violated or restricted for disciplinary or any other purpose ....'

2 Whittaker $v$ Roos and Bateman; Morant $v$ Roos and Bateman 1912 AD 92. In that matter, the newly constituted Appellate Division of the Union of South Africa held that prisoners of all kinds were entitled to 'all the personal rights and personal dignity not temporarily taken away by law, or necessarily inconsistent with the circumstances in which they had been placed.'

3 In 1998 the South African Police Service (SAPS) reported crime figures included: 88319 instances of aggravated robbery, 24875 murders, 49754 rapes, 256434 assaults with intent to inflict grievous bodily harm, and 360919 burglaries.

4 The Criminal Law Amendment Act 105 of 1997, which came into effect in 1998, created a range of minimum sentences for a long list of 'serious offences', despite the South African Law Reform Commission having recommended a thorough debate before a new sentencing regime be introduced. The swiftness with which this legislation was passed can be attributed largely to the government's aspiration to be seen as 'tough on crime', at a time when crime was reportedly on the increase 
and public tension high. The minimum sentences range from life imprisonment for specified aggravated forms of murder and rape to set numbers of years for first offenders and recidivists for offences listed in the schedules to the Act. The sentences have to be imposed on adult offenders unless substantial and compelling circumstances exist which justify the imposition of lesser sentences.

5 The European Committee for the Prevention of Torture and Inhuman or Degrading Treatment or Punishment (CPT) is the torture prevention committee of the Council of Europe. The CPT was founded on the basis of the European Convention for the Prevention of Torture and Inhuman or Degrading Treatment or Punishment (1987). It allows the CPT to visit all 'places of detention' of the member states of the Council of Europe. The CPT has stated that $10 \mathrm{~m}^{2}$ of floor space per prisoner is a desirable standard and that that anything below $4 \mathrm{~m}^{2}$ per prisoner in a communal cell and $6 \mathrm{~m}^{2}$ for a single cell is 'not a satisfactory amount of living space'. See Report to the Polish Government on the visit to Poland carried out by CPT from 30 June to 12 July 1996, Council of Europe, CPT/Inf (1998) 13; Report to the Albanian government on the visit to Albania carried out by the CPT from 9 to 19 December 1997, Council of Europe, CPT/Inf (2003) 6.

6 See 'Police called in to contain protest at Grootvlei prison' City Press 8 November 2011; 'Stampede at Groenpunt prison after riot and fires' Business Day 8 January 2013; 'Gang fight at Pollsmoor, 10 injured' News 2425 January 2013. Groenpunt, Gootvlei and Pollsmoor are all on the list referred to above.

7 One of these cases was Strydom v Minister of Correctional Services 1999 (3) BCLR 342 (W). The High Court was called to determine whether long-term maximum security prisoners had a right of access to electricity where the Department of Correctional Services had allowed the privilege of having electrical appliances in their cells. Schwartzman J stated (para 15):

To deprive them entirely and in perpetuity of this prospect could also result in their being 'treated and punished in a cruel or degrading manner' (section 12(1)(c) of the Constitution) or their being detained in conditions that are inconsistent with human dignity (section 35(2) of the Constitution).

8 Unlike the International Convention on Civil and Political Rights (ICCPR) and the similarlythemed African and Inter-American regional charters, the European Convention for the Protection of Human Rights and Fundamental Freedoms (the Convention) does not contain two provisions separating the prohibition of torture (torture provision) from the right of detained persons to be treated with respect for their inherent dignity (dignity provision). The Convention contains only the former provision, article three. Perhaps this is why it is only in the last thirteen years or so that the European Court of Human Rights (ECHR) has found that certain conditions of detention amount to a violation of article three (Rodley: 2011). In the first of these cases, a Grand Chamber of the ECHR, in Kudta $v$ Poland No 30210/96) ECHR 2000-XI quite clearly found that article three includes a 'dignity provision' element:

The state must ensure that a person is detained in conditions which are compatible with respect for his human dignity, that the manner and method of the execution of the measure do not subject him to distress or hardship of an intensity exceeding the unavoidable level of suffering inherent in detention and that, given the practical demands of imprisonment, his health and wellbeing are adequately secured by, among other things, providing him with the requisite medical assistance.

9 In 2005 the NPA published a set of guidelines (ATD Guidelines) intended to sensitise prosecutors as to the various options available to try to reduce the number of awaiting-trial detainees. For the most part they are a condensed version of the statutory bail provisions but do offer a couple of meaningful recommendations. It is worth noting, however, that as early as 1999 the NPA was making a concerted effort to combat case backlogs, including the institution of Saturday courts and the deployment of more experienced magistrates and court officials to the busier court centres in the country

10 A number of backlog programmes have been shown to have been effective. See generally Paschke $\mathrm{R}$ (1999). 
11 See for example Mazibuko and Others v City of Johannesburg and Others 2010 (3) BCLR 239 (CC); 2010 (4) SA 1 (CC). There is, however, international precedent for this approach. As Steinberg (supra) notes:

The Council of Europe's CTP has established four square metres per prisoner as a minimum in a communal cell, six square metres in single cells. In the United States, both the American Correctional Association and the American Public Health Association have set standards requiring a minimum of 60 square feet (18.18 square metres) per prisoner. These latter standards have found their way into United States federal regulations; the Bureau of Prisons has used them to establish the rated capacity of its prisons. (In the United States, rated capacity reflects the number of inmates that can be housed safely in a facility.) Courts have used these standards to establish judicially enforceable minima. In the state of Florida, for instance, it is illegal for a prison to exceed its rated capacity. A similar situation prevails in Norway and Holland. In these jurisdictions, the size of the prison population is directly determined by available space.'

12 In Brown v Plata 563 U.S. (2011) the United States Supreme Court, in a 5-4 opinion, ruled that California's prisons were so overcrowded that they violated the Constitution's ban on cruel and unusual punishment. The majority decision describes a prison system failing to deliver minimal care to prisoners with serious health needs, and producing 'needless suffering and death'. Justice Kennedy states:

Overcrowding has overtaken the limited resources of prison staff; imposed demands well beyond the capacity of medical and mental health facilities; and created unsanitary and unsafe conditions that make progress in the provision of care difficult or impossible to achieve. The overcrowding is the primary cause of the violation of [the ban against cruel and unusual punishment].

The remedy, in brief, was an order directing that approximately 36000 prisoners be released or relocated within a two-year period. Put differently, the order required a reduction in prison occupation from 200 per cent to 137.5 per cent. Closer to home, in 2009 the High Court of Malawi handed down Masangano v Attorney General \& Others [2009] MWHC 31 (9 November 2009). The Court insisted that overcrowding - which was, according to official figures, at approximately 200 per cent at the time of the court case - coupled with poor ventilation, had contributed to the deaths of 259 inmates in a space of about eighteen months. It held consequently that the severely overcrowded conditions of detention in certain Malawian prisons amounted to a violation of the right to be free from inhuman and degrading treatment. The Court directed the state to reduce overcrowding by half within eighteen months of the judgment and, with time, to eliminate overcrowding altogether. Notably, there was no supervisory element to the Court's order, making it difficult to determine how well the order was implemented. 
